\title{
Paleolimnological reconstruction of change in a subtropical lake: a comparison of the subfossil record to limnological data
}

\author{
Lourdes Gabito $^{1, *}$, Sylvia Bonilla ${ }^{1}$ and Dermot Antoniades ${ }^{1 \text { y } 2}$ \\ ${ }^{1}$ Sección Limnología, Instituto de Ecología y Ciencias Ambientales, Facultad de Ciencias. Universidad de la \\ República Iguá 4225, CP 11400 Montevideo, Uruguay. Fax: + 5982-25258617. \\ ${ }^{2}$ Centre for Northern Studies (CEN: Centre d’Études Nordiques), Université Laval, Québec, Québec, Canadá. \\ *Corresponding author: Igabito@fcien.edu.uy
}

Received: 22/11/2011

Accepted: 29/01/2013

\begin{abstract}
Paleolimnological reconstruction of change in a subtropical lake: a comparison of the subfossil record to limnological data

Paleolimnological techniques permit the reconstruction of past environmental and biological conditions in aquatic ecosystems. However, more studies that include comparisons with historical and limnological records are needed, particularly in subtropical and tropical regions, to validate the links between extant and subfossil indicator communities. We performed a paleolimnological study to reconstruct environmental changes over the last 11 years in Lake Rodó, a subtropical, hypereutrophic shallow lake located in Uruguay $\left(34^{\circ} 54^{\prime} 45^{\prime \prime} \mathrm{S}, 56^{\circ} 10^{\prime} 01^{\prime \prime} \mathrm{W}\right)$, which was subjected to rehabilitation measures and from which limnological data were available. Analyses of the composition and abundance of fossil diatoms divided the record into three time periods that coincided with events during the history of Lake Rodó and its rehabilitation. The most abundant species were Aulacoseira granulata, Synedra acus, Aulacoseira granulata var. angustissima, Achnanthidium minutissimum, Stephanodiscus hantzschii and Fragilaria crotonensis. Indices of planktonic/benthic subfossil diatoms and of diversity reflected changes in the transparency of lake water and in the diversity of habitats available for growth. Records of diatom abundances from phytoplankton and sediment samples were highly correlated; these results highlight the value of diatoms as bioindicators for reconstructing environmental conditions even on short time scales (sub-decadal). Our results also show important differences between temperate and subtropical systems and highlight the need for caution when attempting to apply ecological data determined in other regions.
\end{abstract}

Key words: Diatoms, lake restoration, environmental changes, paleolimnology.

\section{RESUMEN}

Reconstrucción de cambios limnológicos en un lago subtropical: comparación de registros de diatomeas subfósiles y actuales

A través de la paleolimnología es posible obtener un perfil histórico y reconstruir las condiciones biológicas y ambientales pasadas de un sistema acuático. Sin embargo, son necesarios más estudios que comparen registros históricos y actuales para validar estas reconstrucciones en sistemas subtropicales. En este trabajo realizamos un estudio paleolimnológico para reconstruir cambios ambientales en los últimos 11 años en el Lago Rodó, un lago subtropical somero situado en Uruguay ( $34^{\circ} 54^{\prime} 45^{\prime \prime} S, 56^{\circ} 10^{\prime} 01^{\prime \prime} \mathrm{W}$ ), que fue sometido a medidas de rehabilitación y del cual se tienen datos limnológicos. El análisis de la composición y abundancia de especies de diatomeas subfósiles mostró tres períodos en el tiempo que coincidieron con distintos eventos en la historia del lago y su rehabilitación. Las especies más abundantes fueron Aulacoseira granulata, Synedra acus, Aulacoseira granulata var. angustissima, Achnanthidium minutissimum, Stephanodiscus hantzschii y Fragilaria crotonensis. Los índices de diatomeas subfósiles planctónicas/bentónicas y de diversidad reflejaron cambios en la transparencia del agua y en la diversidad de hábitats disponibles para el crecimiento de las diatomeas. Los perfiles temporales de abundancia absoluta de diatomeas subfósiles y diatomeas actuales en agua mostraron una alta correlación entre sí, subrayando el alto valor de las diatomeas como bioindicadores aún en un lapso corto de tiempo (sub-decadales). 
Nuestros resultados también remarcan diferencias importantes entre ambientes subtropicales y templados indicando que se debe tener precaución al aplicar datos ecológicos de especies que fueron citadas para otras regiones.

Palabras clave: Diatomeas, rehabilitación, cambios ambientales, paleolimnología.

\section{INTRODUCTION}

The histories of lakes can be inferred from their sediments, which preserve a wide variety of biological and geochemical information about depositional environments. One of the most effectively applied tools in paleolimnological studies has been the study of microfossils such as diatoms. These siliceous organisms preserve well in lake sediments, they have strong habitat affinities, they reproduce rapidly and their species composition reliably records changes in their environment (Stoermer \& Smol, 1999). Diatoms are therefore useful for evaluating environmental change in lakes on a variety of time scales. Studies of fossil or subfossil diatoms permit the reconstruction of past nutrient levels, climate change, or the consequences of the application of rehabilitation measures in lakes (Battarbee et al., 2012; Smol, 2002). The large majority of studies that have reconstructed environmental or trophic change have been focused on temperate lakes in the northern hemisphere (e.g., Anderson \& Odgaard, 1994; Anderson et al., 1993; Bennion et al., 1996; Bennion \& Simpson, 2011; Dong et al., 2008). Despite the differences between subtropical lakes and their temperate and tropical counterparts (Schiemer \& Boland, 1996; Reynolds, 2006), there are relatively few published paleolimnological studies from subtropical ecosystems. During the last decade, studies have begun to address this deficiency, including those concerned with the effects of anthropogenic activities (Engstrom et al., 2006; García-Rodríguez et al., 2002) and the reconstruction of trophic changes (García-Rodríguez et al., 2004; Parra et al., 2003).

The remediation of eutrophic lakes is common in temperate ecosystems and may include such diverse measures as the control of nutrient

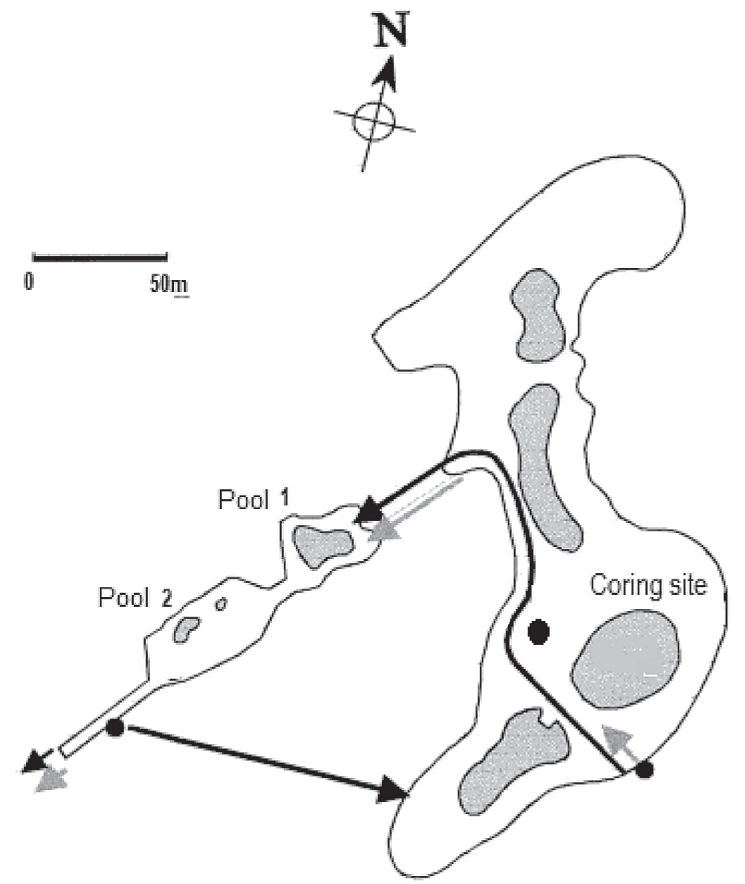

Figure 1. Map of Lake Rodó indicating the location of core sampling. The grey arrows indicate the movement of groundwater and the black arrows indicate the direction of the circulation between the lake and adjacent pools (Modified from Scasso et al., 2001). Mapa del lago Rodó. Se indica el lugar donde fue extraído el testigo. Las flechas grises indican la circulación del agua subterránea, las flechas negras indican el sentido de la circulación posterior entre el lago y las piscinas adyacentes (Modificado de Scasso et al., 2001).

loads and biomanipulation, with varying degrees of effectiveness (Jeppesen et al., 2007). In some ecosystems, paleolimnological reconstructions have later been used to evaluate the impact of these measures (e.g., Valero-Garcés et al., 2006; Wessels et al., 1999); again, such studies in subtropical ecosystems are rare (RiedingerWhitmore et al., 2005; Schelske \& Kenney, 2001). Comparisons of paleolimnological reconstructions with limnological data, where avail- 
able, are key for evaluating the efficacy of paleolimnological methods for recording environmental change on short time scales (years to decades) and may also enable predictions about future lake trajectories (Battarbee et al., 2012).

In this study, we examined Lake Rodó, an urban lake in Montevideo, Uruguay, from which limnological data are available for parts of the last two decades. Our objectives were 1) to reconstruct environmental changes using subfossil diatoms from a shallow, hypereutrophic, subtropical lake in which remediation measures had been applied and 2) to compare the limnological and subfossil diatom records to evaluate the reliability of paleolimnological methods in this ecosystem type.

\section{MATERIALS AND METHODS}

\section{Study area}

Lake Rodó $\left(34^{\circ} 54^{\prime} 45^{\prime \prime} \mathrm{S} ; 56^{\circ} 10^{\prime} 01^{\prime \prime} \mathrm{W}\right)$, located in Montevideo, Uruguay, is a small $($ area $=1.5 \mathrm{ha})$, shallow $\left(Z_{\max }=2.5 \mathrm{~m}\right)$ artificial lake in an urban park and is used for recreational purposes. Its waters are hypereutrophic (Scasso et al., 2001) (Fig. 1). The lake is turbid (transparency $0.15-0.30 \mathrm{~m}$ ), has high phytoplankton biomass (99-335 $\mu \mathrm{g} / \mathrm{l}$ chlorophyll $a$, chl- $a$ ) and prior to the application of remediation measures, was generally dominated by Planktothrix agardhii and other filamentous cyano- bacteria (Sommaruga, 1995).

Beginning in 1996, remediation measures were applied to Lake Rodó with the goal of increasing transparency and reducing phytoplankton biomass (Fig. 2). In the spring of 1996, the lake was completely drained and its modern organic sediments were removed, exposing the basal sediments that existed prior to the construction of the lake (i.e., pre-1917). Between January 1997 and January 1998, the lake was refilled by pumping $\left(360 \mathrm{~m}^{3} /\right.$ day $)$ nutrient-rich groundwater into the basin (Scasso et al., 2001). In July 1998, the groundwater supply to the lake was halted; it was later reconnected intermittently until January 2006, when it was eliminated (Aubriot, 2008; Rodríguez-Gallego et al., 2004) (Fig. 2). Additionally, in July 1998, a recirculation system $\left(170 \mathrm{~m}^{3} /\right.$ day $)$ was installed that circulated water between the lake and two adjacent pools covered with macrophytes, with the goal of removing dissolved nutrients from the water (Rodríguez-Gallego et al., 2004). In July 1999, the recirculation system broke; it was reinstalled in February 2000, from which time it was in operation until 2005 (Aubriot, 2008). Biomanipulation measures were also applied, including the removal of omnivorous fish in winter and spring of 1997, 1998 and 1999, as well as the introduction of native piscivorous fish in spring 1997 (Rodríguez-Gallego et al., 2004). The remediation measures resulted in a reduction of phytoplankton biomass and total phosphorus (TP) (to $<20 \mu \mathrm{g} / 1 \mathrm{chl}-a$ and $66 \mu \mathrm{g} / \mathrm{l} \mathrm{TP}$ ) at the

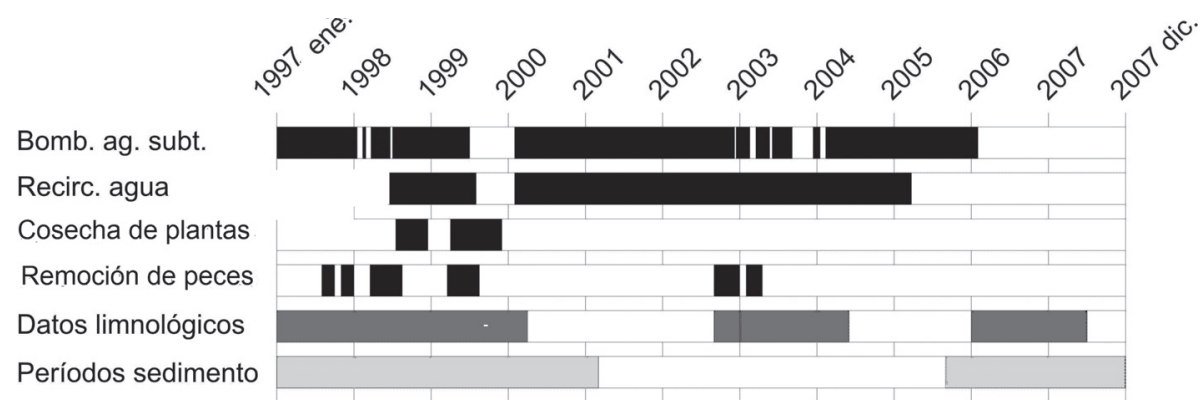

Figure 2. Summary of remediation measures in Lake Rodó from its draining in 1996 until December 2007 (black bars), the periods with limnological information (dark grey bars) and the periods as defined from subfossil diatom communities (light grey and white bars). Resumen de las medidas de rehabilitación lago Rodó luego del vaciado del mismo en 1996 hasta diciembre de 2007 (barras negras), los períodos con información limnológica (barras gris oscuro) y los tres períodos definidos por las comunidades de diatomeas subfósiles (barras gris claro y blanco). 
of phytoplankton biomass and total phosphorus (TP) (to $<20 \mu \mathrm{g} / \mathrm{l}$ chl- $a$ and $66 \mu \mathrm{g} / \mathrm{l} \mathrm{TP}$ ) at the beginning of 1997 (Scasso et al., 2001). Early successes notwithstanding, more recent studies indicate that the lake has returned to its earlier hypereutrophic state (106-204 $\mu \mathrm{g} / \mathrm{l}$, average chl- $a$ values for January and March 2007) (Aubriot et al., 2011). The phytoplankton at this time was dominated by filamentous cyanobacteria, and the community composition closely resembled that recorded prior to the lake's restoration, although diatoms dominated the community during 2007 (Aubriot, 2008). Beginning in 2005, there was a natural increase in the abundance of the macrophyte Potamogeton pectinatus, which progressively occupied a greater proportion of the lake's surface area (Rodríguez-Gallego, pers. comm.).

\section{Sample collection and dating}

On 28 December 2008, we extracted a $21 \mathrm{~cm}$ sediment core from the deepest point of Lake Rodó (Fig. 1). The core was immediately sectioned in the laboratory, with the upper $5 \mathrm{~cm}$ sliced every $0.5 \mathrm{~cm}$, the next $10 \mathrm{~cm}$ at $1 \mathrm{~cm}$ intervals and the lower $6 \mathrm{~cm}$ at $2 \mathrm{~cm}$ intervals. These $23 \mathrm{sam}$ ples were kept in a freezer $\left(-20{ }^{\circ} \mathrm{C}\right)$ until analysis. Given the removal of all lacustrine sediment in 1997, the organic sediments of the core corresponded to the period after the lake was refilled (January-February 1997), representing 11 years. We used two independent methods to establish the depth in the core at which the transition occurred between modern sediments (i.e., post-dredging) and those from before the lake's construction. We measured ${ }^{210} \mathrm{~Pb}$ activities (Appleby, 2001) to detect any deviation from the expected logarithmic decay curve that might indicate a disconformity in the sediments. We also used organic matter analysis by loss-on-ignition (Dean, 1974) to determine the limit between the pre-lacustrine, inorganic sediment and the postrefilling, organic sediment.

\section{Diatoms}

Diatom samples were prepared for analysis by lyophilisation for 24 hours, after which they were oxidised with $30 \% \mathrm{H}_{2} \mathrm{O}_{2}$ for between 4 and 8 hours, as necessary, to eliminate all organic material. Samples were centrifuged at $1200 \mathrm{rpm}$ for 15 minutes and were rinsed with distilled water; this rinsing step was repeated three times. Aliquots of divinylbenzene microspheres of known concentration were then added as external markers and slides were prepared using Entellan mounting medium. Diatoms were identified to the species or subspecies level following the taxonomic concepts of Metzeltin et al. (2005), Krammer \& Lange-Bertalot, (1986-1991) and Antoniades et al. (2008). Species relative abundances were calculated based on a minimum count of 300 valves per sample using an optical microscope at $1000 \times$ magnification. We calculated absolute abundances following the method of Battarbee (1986) and concentrations are expressed as valves per gram dry sediment. Diatom species were classified as benthic or planktonic; all life forms that live on sediment or attached to any substrate (i.e., periphytic or epiphytic) were considered to be benthic for the purposes of calculating the ratio of planktonic to benthic taxa.

In order to compare the records from limnological measurements with those from the sedimentary record, we compiled all available limnological data from Lake Rodó, including total diatom abundances as well as abiotic variables $\left(\mathrm{K}_{d}\right.$ : light extinction coefficient, TP: total phosphorus, TN: total nitrogen, DIN: dissolved inorganic nitrogen, Temp: water temperature and chl-a) (Aubriot, 2008; Kruk, 2001; Kruk et al., 2002; Meerhoff et al., 2003; Rodríguez-Gallego, 2003, 2004; Scasso et al., 2001 and unpublished data kindly provided by Carla Kruk and Luis Aubriot). These limnological data came from numerous studies with diverse objectives and therefore varied in the time of year as well as the frequency of sampling (weekly, bi-weekly or monthly) (Figs. 2 and 3). Only total abundance data were available for diatoms, as identifications to the genus and species levels were not made in these studies.

\section{Data analysis}

Cluster analysis was used to examine variability in the subfossil diatom assemblages over 
time. We used K-means clustering to analyse the Hellinger-transformed relative abundance species dataset, and the Calinski-Harabasz pseudo-F statistic was used to determine the most appropriate number of clusters (Legendre \& Legendre 1998). To facilitate comparisons in the discussion, the remediation measures and available limnological data were classified into the same time periods represented by the K-means clusters (Figs. 2 and 3).
Broad changes in community characteristics were also examined using the ratio of planktonic:benthic taxa $(\mathrm{P} / \mathrm{B})$ and Hill's N2 index of diversity (Hill, 1973), both calculated from untransformed relative abundance data. To determine if diversity was affected by the availability of different substrates or habitats, we related diversity with the $\mathrm{P} / \mathrm{B}$ index using Spearman's non-parametric correlation coefficient. We used ordinary least squares regression
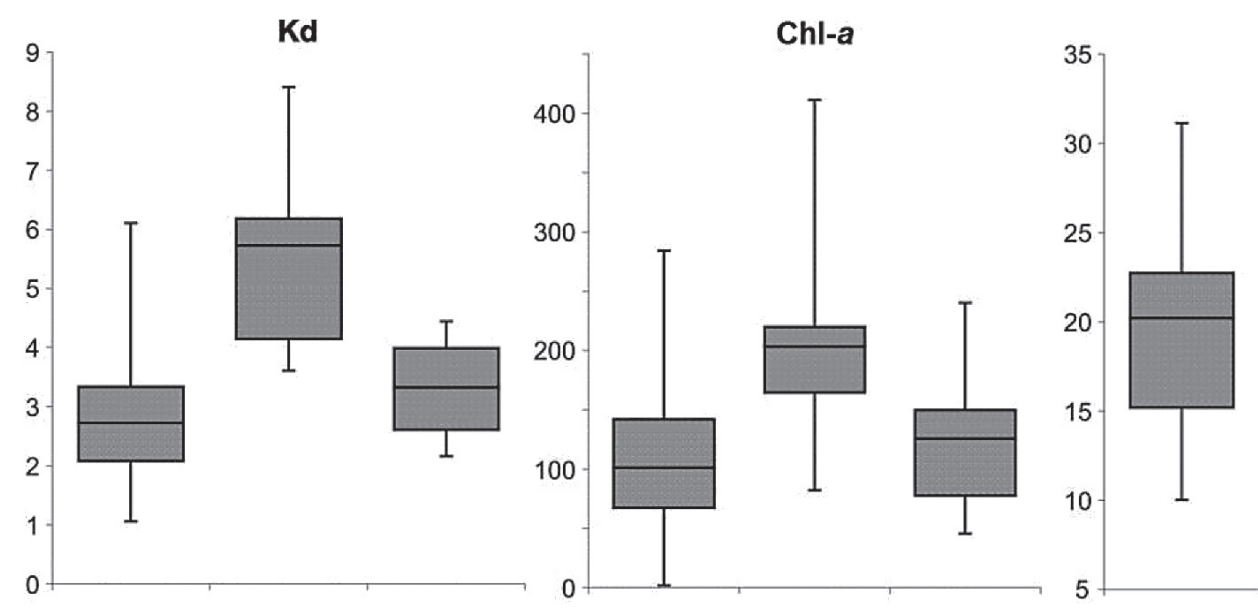

Temp
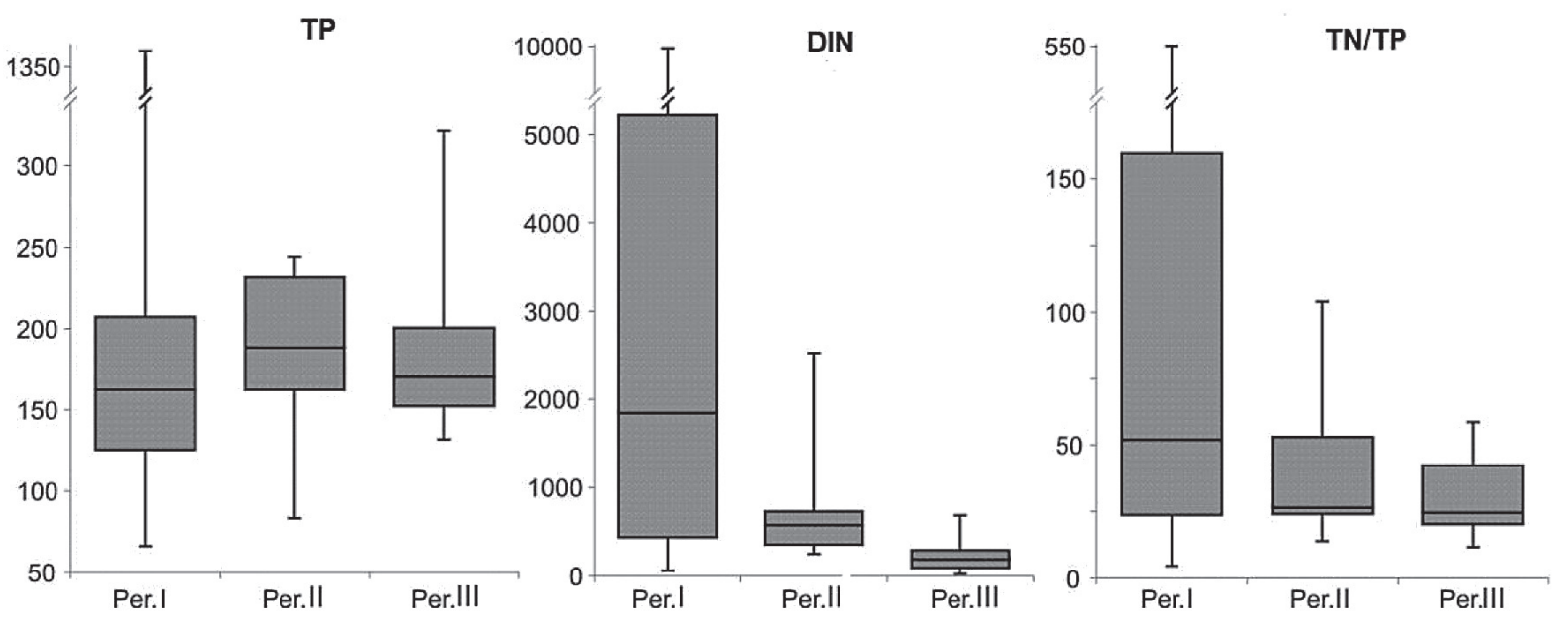

Figure 3. Boxplots of Lake Rodó limnological variables for paleolimnological periods (several sources, see references in Material and methods), $\mathrm{K}_{d}$ : light extinction coefficient, chl- $a$ : chlorophyll $a$, Temp: temperature, TP: total phosphorus, DIN: dissolved inorganic nitrogen, TN/TP: ratio of total nitrogen/total phosphorus. Diagramas de caja de variables limnológicas del Lago Rodó para los períodos paleolimnológicos (diversas fuentes, ver referencias en Materiales y métodos), $K_{\mathrm{d}}$ : coeficiente de extinción de la luz, chl-a: clorofila a, Temp: temperatura, TP: fósforo total, DIN: nitrógeno inorgánico disuelto, TN/TP: relación nitrógeno total/fósforo total. 
to compare the relationship between subfossil diatom abundances and those from limnological measurements. Due to the difference in temporal resolution between subfossil ( annual) and limnological (weekly to monthly) diatom records, we used monthly averages of the limnological data and only included in the calculations those periods from the sediment for which corresponding limnological data were available (i.e., 14 samples). For these regressions, diatom abundances were normalised by $\log _{10}$ transformation (Kolmogorov-Smirnov, $d=0.095, \quad p>0.05$ ). Statistical analyses were performed using the software packages K-means, SigmaPlot 11.0, STATISTICA 6 and C2 version 1.4.3.

\section{RESULTS}

\section{Dating}

${ }^{210} \mathrm{~Pb}$ activities followed the expected log decay curve until there was a sharp deviation in the bottom interval $(19-21 \mathrm{~cm})$. At this same horizon there was a sudden decrease in the concentration of organic matter (Fig. 4), and the organic sediments were visually darker and finer than the coarse, inorganic basal sediments. As the transition between pre-lake sediments and those deposited following the refilling of the lake was observed at the same level with two independent markers, we assigned the date of January 1997 to the $19 \mathrm{~cm}$ level. Above

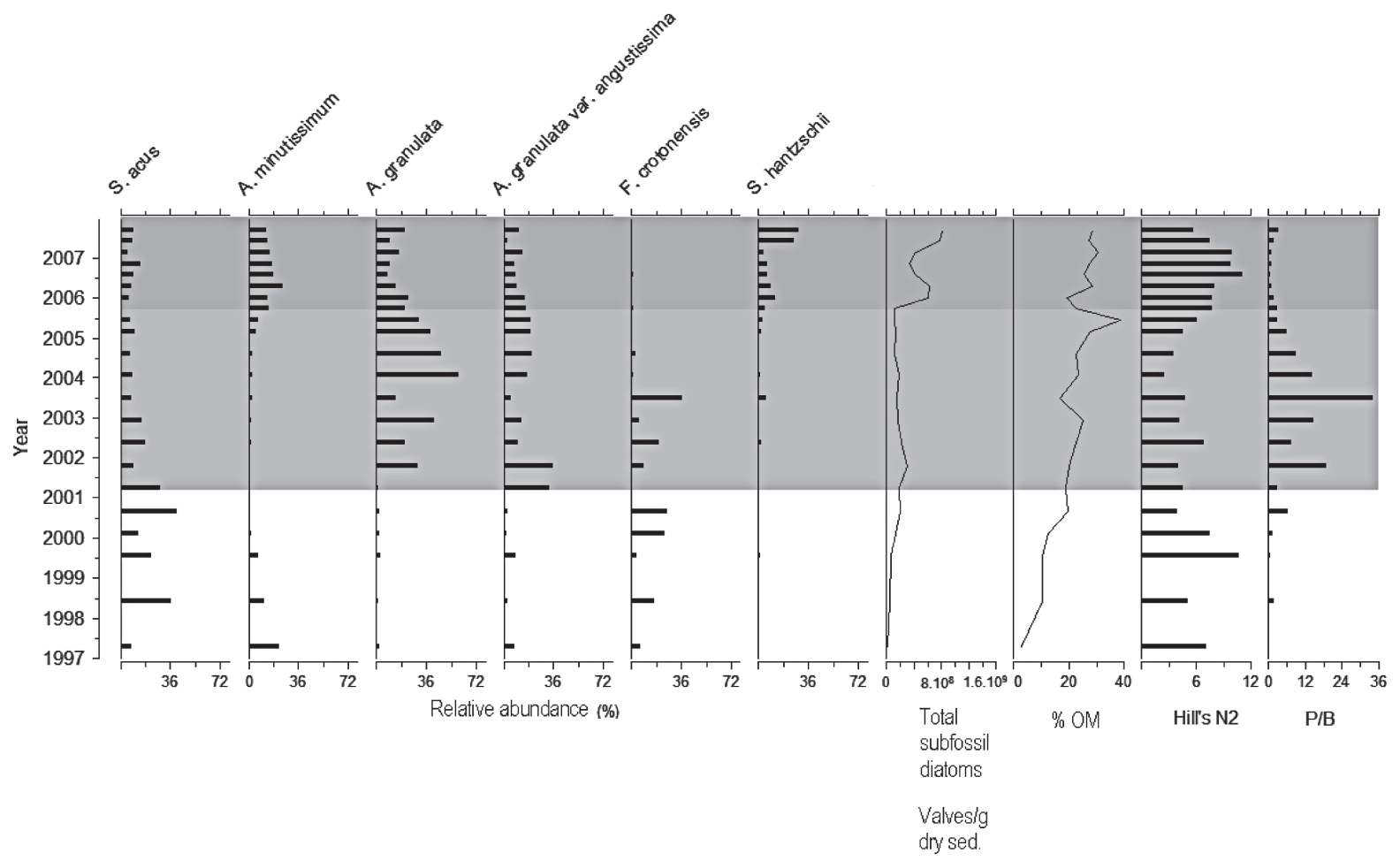

Figure 4. Relative abundance of the six most abundant subfossil diatom taxa in the Lake Rodó core (Synedra acus, Achnanthidium minutissimum, Aulacoseira granulata, Aulacoseira granulata var. angustissima, Fragilaria crotonensis and Stephanodiscus hantzschii), absolute abundance of diatoms in the core (total subfossil diatoms), percent organic matter (\% OM), planktonic/benthic (P/B) diatom index and Hill's N2 diversity. The different colours represent the three periods referred to in the text: White: period I, light grey: period II, dark grey: period III. Abundancia relativa de los seis taxones de diatomeas subfósiles más abundantes en el testigo del Lago Rodó: Synedra acus, Achnanthidium minutissimum, Aulacoseira granulata, Aulacoseira granulata var. angustissima, Fragilaria crotonensis y Stephanodiscus hantzschii, abundancia absoluta de las diatomeas en el testigo (Diat. Subfósiles Totales), porcentaje de materia orgánica $(\% O M)$, índices de diatomeas $P / B=$ Planctónicas/Bentónicas y el índice de diversidad Hill's N2. Los diferentes colores representan los tres períodos, blanco: período I, gris claro: período II y gris oscuro: período III. 
this horizon we calculated ages based on a constant sedimentation rate of $1.7 \mathrm{~cm}$ per year. It is probable that the rate of sedimentation varied somewhat during the 11 years of deposition, which would imply small errors in our age model. However, any errors generated are smaller than typical error values in the published literature calculated based on ${ }^{210} \mathrm{~Pb}$ and other methods. Additionally, due to bioturbation, it is unlikely that seasonal variation was preserved in the sedimentary record. When combined with insufficient temporal resolution below $5 \mathrm{~cm}$, this prevented us from inferring shifts in subfossil diatom communities caused by seasonality.

The K-means analysis indicated that the core was best divided into three clusters (with 6, 9 and 8 samples in each). Although the analysis was not restricted to contiguous sample groups, the resulting clusters represented three distinct time periods with no overlap. These clusters corresponded to (I) March 1997 to March 2001 (6 samples); (II) March 2001 to September 2005 (9 samples) and (III) September 2005 to December 2007 (8 samples).

\section{Composition and abundance of subfossil diatoms}

Thirty-two diatom species belonging to 18 genera were identified in the sediment core (Table 1). Of these, there were five centric and 27 pennate taxa, with seven planktonic and 25

Table 1. List of subfossil diatom taxa found in the core. Habitat type: P: planktonic, B: benthic. Lista de especies de diatomeas subfósiles encontradas en el testigo. Se indica el hábitat: $P$ : planctónica, B: bentónica.

\begin{tabular}{|c|c|c|c|}
\hline \multirow{2}{*}{$\begin{array}{l}\text { Centric diatoms } \\
\text { Discostella stelligera (Cleve \& Grunow) }\end{array}$} & & \multicolumn{2}{|l|}{ Pennate diatoms } \\
\hline & & & \\
\hline Houk \& Klee & $\mathrm{P}$ & Achnanthes inflata (Kützing) Grunow & B \\
\hline Aulacoseira granulata (Ehrenberg) Simonsen & $\mathrm{P}$ & Achnanthidium minutissimum (Kützing) Czarnecki & B \\
\hline \multicolumn{4}{|l|}{ Aulacoseira granulata var. angustissima } \\
\hline (O. F. Müller) Simonsen & $\mathrm{P}$ & Amphora veneta Kützing & $\mathrm{B}$ \\
\hline Cyclotella meneghiniana Kützing & $\mathrm{P}$ & Cocconeis placentula Ehrenberg & $\mathrm{B}$ \\
\hline \multirow[t]{23}{*}{ Stephanodiscus hantzschii Grunow } & $\mathrm{P}$ & Cymbella excisa var. angusta Krammer & B \\
\hline & & Encyonema cf. reichardtii (Krammer) D. G. Mann & B \\
\hline & & Encyonema cf. vulgare Krammer & $\mathrm{B}$ \\
\hline & & Epithemia adnata (Kützing) Brébisson & $\mathrm{B}$ \\
\hline & & Epithemia sorex Kützing & B \\
\hline & & Fragilaria crotonensis Kitton & $\mathrm{P}$ \\
\hline & & Gomphonema batei Metzeltin, Lange-Bertalot \& García-Rodríguez & $\mathrm{B}$ \\
\hline & & Gomphonema parvulum (Kützing) Kützing & $\mathrm{B}$ \\
\hline & & Gomphonema uruguayense & \\
\hline & & Metzeltin, Lange-Bertalot \& García-Rodríguez & $\mathrm{B}$ \\
\hline & & Gomphonema sp. & $\mathrm{B}$ \\
\hline & & Navicula sp. 1 & $\mathrm{~B}$ \\
\hline & & Nitzschia sp. 1 & $\mathrm{~B}$ \\
\hline & & Nitzschia amphibia Grunow & $\mathrm{B}$ \\
\hline & & Nitzschia denticula Grunow & $\mathrm{B}$ \\
\hline & & Nitzschia hungarica Grunow & $\mathrm{B}$ \\
\hline & & Nitzschia intermedia Hantzsch ex Cleve \& Grunow & $\mathrm{B}$ \\
\hline & & Nitzschia palea (Kützing) W. Smith & B \\
\hline & & Nitzschia sigma (Kützing) W. Smith & $\mathrm{B}$ \\
\hline & & Pinnularia sp. 1 & B \\
\hline & & Rhoicosphenia abbreviata (Agardh) Lange-Bertalot & B \\
\hline & & Surirella ovalis Brébisson & $\mathrm{B}$ \\
\hline & & Synedra acus Kützing & $\mathrm{P}$ \\
\hline
\end{tabular}


benthic taxa (Table 1). Species composition varied notably over time (Fig. 4). The taxa with the highest relative abundances during the first period were Synedra acus, with maximum/median relative abundances of 41.2/25.7\%; Fragilaria crotonensis, with abundances of 26.3/11.7\% and Achnanthidium minutissimum, with abundances of 22.5/3.9\% (Fig. 4). The abundances of Encyonema reichardtii showed trends similar to those of A. minutissimum, with a maximum abundance of $24.5 \%$ in 1997, followed by a pronounced drop until 2000, after which its maximum relative abundance was $1.7 \%$ (data not shown). During the second period, Aulacoseira granulata, A. granulata var. angustissima and $F$. crotonensis were dominant, reaching relative abundances of $60.1 / 31.2 \%, 35.9 / 17.2 \%$ and $36.7 / 3.1 \%$ (max./med.), respectively. Finally, during period III, Stephanodiscus hantzschii, A. minutissimum and $A$. granulata were dominant, with maximum/median abundances of 68.9/10.9\%, 24.9/ $14.4 \%$ and $23.2 / 11.9 \%$, respectively.

\section{$\mathbf{P} / \mathbf{B}$ index and diversity}

Planktonic diatoms represented an average of $72 \%$ of the diatom assemblage and in only four of the 23 samples did benthic abundances exceed those of planktonic taxa. The $\mathrm{P} / \mathrm{B}$ index varied between 0.5 and 34.3 , with an average of 6.4 (Fig. 4). The index showed minimum values before 2001, rose sharply in 2002 with elevated but variable values until $\approx 2005$, followed by low values after this date (Fig. 4). Conversely, diversity (i.e., Hill's N2) was high before 2000 , decreased until $\approx 2005$ and returned to higher values after 2005 (Fig. 4). The diversity and P/B indices were significantly negatively correlated $\left(r^{2}=-0.80, p<0.05\right)$.

\section{Subfossil vs. limnological diatom abundances}

Absolute abundances of diatoms in limnological samples were highly correlated with their coeval subfossil samples $\left(r^{2}=0.84 ; p<0.01\right)$ (Fig. 5a), with no trend present in the residuals (Fig. 5b). In the oldest part of the core both subfossil and limnological diatom abundances were low and remained so until $\approx 2000$, when both increased. The core was characterised by moderate diatom abundances from this date onwards, with the exception of two peaks in abundance in 2006 and 2007, which were observed both in lake and core samples (Fig. 5a).
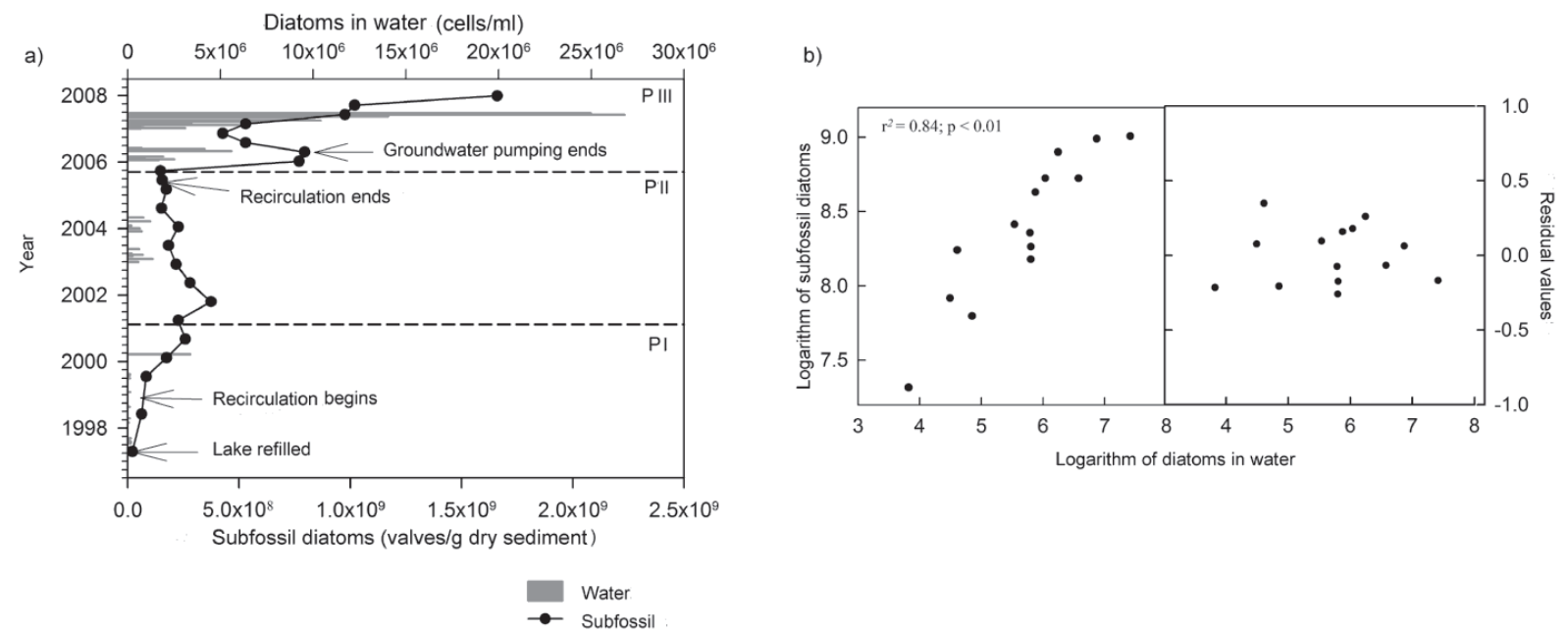

Figure 5. a) Changes over time in the abundance of subfossil diatoms calculated from the sedimentary record (bars) and diatoms in water samples (line and circles), b) graphical log-linear regression of diatoms in water vs. subfossil diatoms and regression residuals. a) Abundancia de diatomeas subfósiles en el testigo (barras) y de diatomeas en agua calculada de muestras limnológicas (línea y círculos) a lo largo del tiempo, b) gráfica de la regresión lineal de logaritmo de diatomeas en agua vs. logaritmo de diatomeas subfósiles y los valores residuales. 


\section{DISCUSSION}

Shifts in the subfossil diatom community reflected environmental changes, such as the gradual increase in trophic state of Lake Rodó after its refilling (1997) and its later return to a hypereutrophic state (Scasso et al., 2001; Rodríguez-Gallego et al., 2004; Aubriot et al., 2011). While the use of diatoms for the identification of past trophic changes is well established (e.g., Battarbee et al., 2012; Bennion et al., 1996; Bennion \& Simpson, 2011; Yao et al., 2011), few studies have tested the reliability of this methodology in subtropical lakes (Engstrom et al., 2006; García-Rodríguez, 2006; Parra et al., 2003). The highly correlated absolute abundances of diatoms in limnological and core samples suggest that the sedimentary record in Lake Rodó is reliable and that it has recorded changes on sub-decadal time scales. Moreover, events in the remediation history of Lake Rodó and changes in the lake's limnological characteristics were recorded in the sedimentary diatom record and by the three periods identified by cluster analysis.

\section{Period I: March 1997-March 2001}

This period coincides with the refilling of the lake and the initiation of remediation measures that initially resulted in increased transparency $\left(K_{d}=1.41 / \mathrm{m}\right)$ and reduced phytoplankton biomass (chl- $a=13 \mu \mathrm{g} / \mathrm{l}$ ) for a short period of time during 1997 (Scasso et al., 2001). This effect likely resulted from a reduction in the nutrient load of the ecosystem, leading to nutrient concentrations typical of mesotrophic systems (Kruk et al., 2002; Scasso et al., 2001). The most abundant species in the core during this period were Synedra acus, an indicator of mesotrophy (Wang et al., 2012) and Fragilaria crotonensis, which is typical of mesotrophic to eutrophic environments (Pienitz et al., 2006; Reavie et al., 2000; Saros et al., 2011). Another important component of the diatom assemblage during this time was Achnanthidium minutissimum, which is present in lakes of highly divergent nutrient concentrations (NRC, 2011) and therefore cannot be used as an indicator of trophic status. However,
A. minutissimum is often among the first taxa to colonise aquatic environments and to dominate communities following habitat disturbance (Peterson \& Stevenson 1992), which may explain its high relative abundance in Lake Rodó immediately after refilling and its subsequent gradual decrease with the stabilisation of the ecosystem. The similarities in the abundance trends of A. minutissimum and Encyonema reichardtii suggest that the latter species may also be considered an indicator of disturbance.

Various factors may have contributed to the relatively low values of the $\mathrm{P} / \mathrm{B}$ index during period I. The relative success of benthic diatoms during the gradual refilling of the lake may have resulted from the reduced water depth. The greatest transparency values were recorded shortly after the refilling of the lake (Fig. 3), with a euphotic zone of $3.3 \mathrm{~m}$, and continued until the recirculation system broke in July 1999 (Rodríguez-Gallego et al., 2004). This transparency suggests high light availability (euphotic zone/mixing zone, $Z_{\mathrm{eu}} / Z_{\text {mix }}$ ratio $=1.32$, assuming that $Z_{\max }=Z_{\text {mix }}$ ) and therefore that the sediments were illuminated throughout period I. The availability of light permitted diatoms to grow in a variety of microhabitats and the success of attached diatoms was therefore responsible for the greater proportion of benthic species.

\section{Period II: March 2001-September 2005}

The changes in the diatom assemblages of the Lake Rodó sediment core between periods I and II reflected notable changes in water quality during this time (Fig. 3 and 4). Kruk et al. (2002) found that the phytoplankton (non-diatom) species composition in the lake during period II was typical of high-nutrient sites. Limnological measurements indicated that mean phytoplankton biomass (i.e., chl- $a$ ) and water temperature increased significantly in period II relative to period I ( $p \leq 0.05)$, while transparency, DIN and TN/TP decreased significantly (Fig. 3); there was no significant difference in TP concentrations. The effects of the failure of the recirculation system may have influenced the aforementioned changes in biomass and transparency; the most 
obvious effect on diatom communities was a shift in the $\mathrm{P} / \mathrm{B}$ ratio. The proportion of benthic diatoms decreased from an average of $39.6 \%$ in period I to $11.9 \%$ in period II. Our results are similar to those of Reavie et al. (2000), who observed a correlation between increased abundances of planktonic taxa and greater trophic status in a eutrophic Canadian lake.

The taxa that dominated subfossil diatom assemblages in period II were Aulacoseira granulata and A. granulata var. angustissima. These are meroplanktonic, filament-forming taxa that are strongly silicified (Kilham et al., 1986). Although we do not have $\mathrm{SiO}_{2}$ data from limnological studies, the dominance of these taxa suggests that silica was not limiting during period II. Both taxa are characteristic of eutrophic environments (Bennion \& Simpson, 2011; Gong et al., 2009; NRC, 2011; Parra et al., 2003; Wessels et al., 1999), have high nitrogen requirements (Kilham \& Kilham, 1975; Moura et al., 2012) and can live on the sediment surface or form cysts that permit their return to growth when conditions are more favourable. Taxa in the genus Aulacoseira also have a lower light saturation intensity $\left(I_{k}\right)$ than other eutrophic species (Talling 1957), which may have favoured their growth as transparency decreased in Lake Rodó. Until the middle of period II, Fragilaria crotonensis was an important component of the diatom community, after which its relative abundance dropped abruptly. The period of its greatest abundance coincided with the removal of fish from Lake Rodó (1997-2003; Fig. 2). Interestingly, the abundance of this taxon also increased during a program of biomanipulation by fish removal in a eutrophic, temperate lake in Finland (Liukkonen et al., 1997), which may suggest that increases in zooplankton biomass favour Fragilaria crotonensis growth. Towards the end of this period, the trophic increase affected the entire diatom community as the lake became dominated by cyanobacteria (Aubriot, 2008).

\section{Period III: September 2005-December 2007}

The diatom species that increased the most during period III were $S$. hantzschii and, once again,
A. minutissimum, while taxa such as A. granulata, A. granulata var. angustissima and Synedra acus maintained high relative abundances (Fig. 4). During this period, TN and chl- $a$ continued to decrease, while transparency rose again and TP did not change significantly (Fig. 3). Stephanodiscus hantzschii, the most abundant diatom in this period, is characteristic of eutrophic to hypereutrophic environments in the Northern Hemisphere (Bennion \& Simpson, 2011; Gong et al., 2009; NRC, 2011; Pienitz et al., 2006; Räsänen et al., 2006; Yao et al., 2011). In the first two periods this species never exceeded $2.6 \%$ relative abundance, but in period III its mean relative abundance increased to $20.5 \%$ and it reached a maximum of $68.9 \%$ in the most recent sediments. Stephanodiscus hantzschii has been observed in eutrophic lakes (Brugam, 1983) and it shows high growth rates in relation to other eutrophic diatom taxa. Moreover, S. hantzschii has high TP requirements and competes poorly when phosphorus is limiting (Van Donk \& Kilham, 1990). With the continued decrease in all forms of nitrogen and without significant changes in phosphorus, perhaps the lake moved from being phosphorus-limited to nitrogen-limited, creating conditions suitable for the success of S. hantzschii and cyanobacteria (Aubriot 2008).

The increase in transparency in period III coincided with low values of the $\mathrm{P} / \mathrm{B}$ index and an increase in the abundance of the macrophyte $P$. pectinatus, which naturally began to cover an increasing proportion of Lake Rodó's surface area shortly before the beginning of the period (L. Rodríguez-Gallego, pers. comm.). The combination of greater transparency and the associated greater habitat diversity available for growth permitted the increase of $A$. minutissimum and a diverse group of benthic taxa to reach a mean relative abundance of $37.7 \%$ during period III.

Other studies have also found a correlation between the abundance of benthic (i.e., epiphytic) taxa and the abundance of macrophytes due to reduced trophic states (Pienitz et al., 2006). Nevertheless, at the end of period III, increased abundances of planktonic taxa explained both the increase in the $\mathrm{P} / \mathrm{B}$ ratio as well as decreases in diversity, coincident with the 
abrupt increase of S. hantzschii. The bloom of this species also coincided with a large decrease in cyanobacterial abundances at the beginning of 2007 (Aubriot 2008). Absolute diatom abundances in both water and core samples continued to increase with the proliferation of S. hantzschii, which is known to form blooms, albeit generally in cold waters (Jung et al., 2011); subfossil diatom abundances reached their maximum value in 2007. Our study mirrors the results of the others that have observed correlations between limnological measurements of diatom abundances and those in sediment cores, also on decadal to sub-decadal scales (Räsänen et al., 2006, Wessels et al., 1999).

The majority of studies that have used diatoms to reconstruct eutrophication, generally in temperate environments, have done so using TP inference models (Bennion et al., 1996; Dong et al., 2008; Hall et al., 1997). It is notable that in our study there were large changes in diatom community composition, with transitions in the importance of benthic and planktonic forms as well as shifts between the dominance of different centric genera, in the absence of significant changes in TP concentrations. This finding may signify that in subtropical environments, such as Lake Rodó, diverse factors including nitrogen, transparency, macrophytes and interactions with other phytoplankton groups may play a more important role than TP in causing changes in diatom communities. If true, this observation would imply that models developed in temperate lakes may not be applicable to subtropical ecosystems and thus that it may not be possible to transfer ecological inferences across ecosystem types. More studies at the regional level are therefore necessary to determine the factors that control diatom community composition along eutrophication gradients in subtropical environments.

\section{ACKNOWLEDGEMENTS}

We are grateful to Warwick F. Vincent for facilitating ${ }^{210} \mathrm{~Pb}$ analyses and to Luis Aubriot, Felipe García-Rodríguez, Carla Kruk, Gissell
Lacerot, Mariana Meerhoff, Federico Quintans and Lorena Rodríguez Gallego for providing data and/or suggestions on the manuscript. This study was partially financed by ANII (FCE2007_353) and the Fonds québécois de la recherche sur la nature et les technologies.

\section{REFERENCES}

ANDERSON, N. \& B. ODGAARD. 1994. Recent palaeolimnology of three shallow Danish lakes. Hydrobiologia, 275/276: 411-422.

ANDERSON, N., B. RIPPEY \& C. GIBSON. 1993. A comparison of sedimentary and diatom-inferred phosphorus profiles: implications for defining predisturbance nutrient conditions. Hydrobiologia, 253: 357-366.

ANTONIADES, D., P. HAMILTON, M. DOUGLAS \& J. P. SMOL. 2008. Diatoms of North America: The freshwater floras of Prince Patrick, Ellef Ringnes and northern Ellesmere Islands from the Canadian Arctic Archipelago. Iconographia Diatomologica, 17, Koeltz. Königstein.

APPLEBY, P. G. 2001. Chronostratigraphic techniques in recent sediments. In: Tracking environmental change using lake sediments. Volume 1. Basin analysis, coring, and chronological techniques. Last, W. M. \& J. P. Smol (eds.): 171-203. Kluwer Academic Publishers. Dordrecht. The Netherlands.

AUBRIOT, L. 2008. Flexibilidad de la cinética de incorporación de fosfato por fitoplancton a las fluctuaciones en el suministro del nutriente. Doctoral Thesis, Facultad de Ciencias. Universidad de la República. Montevideo.

AUBRIOT, L., S. BONILLA \& G. FALKNER. 2011. Adaptive phosphate uptake behaviour of phytoplankton to environmental phosphate fluctuations. FEMS Microbiology Ecology, 77: 1-16

BATTARBEE, R. 1986. Diatom analysis. In: Handbook of Holocene palaeoecology and palaeohydrology. B. E. Berglund (ed.): 527-570. Chichester, England.

BATTARBEE, R., N. ANDERSON, H. BENNION \& G. L. SIMPSON. 2012. Combining limnological and paleolimnological approaches to disentangle the effects of nutrient pollution and climate change on lake ecosystems: problems and potential. Freshwater Biology, 57: 2091-2106. 
BENNION, H., S. JUGGINS \& N. ANDERSON. 1996. Predicting epilimnetic phosphorus concentrations using an improved diatom-based transfer function and its application to lake eutrophication management. Environmental Science and Technology, 30: 2004-2007.

BENNION, H. \& G. SIMPSON. 2011. The use of diatom records to establish reference conditions for UK lakes subject to eutrophication. Journal of Paleolimnology, 45: 469-488.

BRUGAM, R. B. 1983. The relationship between fossil diatom assemblages and limnological conditions. Hydrobiologia, 98: 223-235.

DEAN, W. 1974. Determination of carbonate and organic matter in calcareous sediments and sedimentary rocks by loss on ignition; comparison with other methods. Journal of Sedimentary Research, 44: $242-248$

DONG, X., H. BENNION, R. BATTARBEE, X. YANG, H. YANG \& E. LIU. 2008. Tracking eutrophication in Taihu Lake using the diatom record: potential and problems. Journal of Paleolimnology, 40: 413-429.

ENGSTROM, D., S. SCHOTTLER, P. LEAVITT \& K. HAVENS. 2006. A re-evaluation of the cultural eutrophication of Lake Okeechobee using multiproxy sediment records. Ecological Applications, 16: 1194-1206.

GARCÍA-RODRÍGUEZ, F. 2006. Inferring paleosalinity trends using the chrysophyte cyst to diatom ratio in costal shallow temperate/subtropical lagoons influenced by sea level changes. Journal of Paleolimnology, 36: 165-173.

GARCÍA-RODRÍGUEZ, F., N. MAZZEO, P. SPRECHMANN, D. METZELTIN, F. SOSA, H. C. TREUTLER, M. RENOM, B. SCHARF \& C. GAUCHER. 2002. Paleolimnological assessment of human impacts in Lake Blanca, SE Uruguay. Journal of Paleolimnology, 28: 457-468.

GARCÍA-RODRÍGUEZ, F., P. SPRECHMANN, D. METZELTIN, L. SCAFATI, D. MELENDI, W. VOLKHEIMER, N. MAZZEO, A. HILLER, W. VON TÜMPLING JR \& F. SCASSO. 2004. Holocene trophic state changes in relation to sea level variation in Lake Blanca, SE Uruguay. Journal of Paleolimnology, 31: 99-115.

GONG, Z-J., Y-I. LI, J. SHEN \& P. XIE. 2009. Diatom community succession in the recent history of a eutrophic Yunnan Plateau lake, Lake Dianchi, in subtropical China. Limnology, 10: 247-253.
HALL, R. I., P. R. LEAVITT, J. P. SMOL \& N. NIRNHELT. 1997. Comparison of diatoms, fossil pigments and historical records as measures of lake eutrophication. Freshwater Biology, 36: 410-417.

HILL, M. O. 1973. Diversity and evenness: A unifying notation and its consequences. Ecology, 2: 427-432.

JEPPESEN, E., M. MEERHOFF, A. JACOBSEN, R. S. HANSEN, M. SØNDERGAARD, J. P. JENSEN, T. L. LAURIDSEN, N. MAZZEO \& W. C. BRANCO. 2007. Restoration of shallow lakes by nutrient control and biomanipulation - the successful strategy varies with lake size and climate. $\mathrm{Hy}$ drobiologia, 581: 269-285.

JUNG, S.W., H.M. JOO, Y-O. KIM, J.H. LEE \& M-S. HAN. 2011. Effects of temperature and nutrient depletion and reintroduction on growth of Stephanodiscus hantzschii (Bacillariophyceae): implications for the blooming mechanism. Journal of Freshwater Ecology, 26: 115-121.

KILHAM, S. S. \& P. KILHAM. 1975. Melosira granulata (Ehr.) Ralfs: Morphology and ecology of a cosmopolitan freshwater diatom. Verhandlungen der Internationalen Vereinigung für Theoretische und Angewandte Limnologie 19: 27 16-2721.

KRAMMER, K. \& H. LANGE-BERTALOT. 19861991. Bacillariophyceae. In: ETTL, H., J. GERLOFF, H. HEYNIG \& D. MOLLENHAUER (eds.) Süßwasserflora von Mitteleuropa. Band 2/1-2/4. Gustav Fischer Verlag, Stuttgart, Germany.

KRUK, C. 2001. Sucesión fitoplanctónica en un lago hipereutrófico en proceso de restauración. Master Thesis, Pedeciba Biología, Universidad de la República. Montevideo.

KRUK, C., N. MAZZEO, G. LACEROT \& C. REYNOLDS. 2002. Classification schemes for phytoplankton: a local validation of a functional approach to the analysis of species temporal replacement. Journal of Plankton Research, 24: 901-912.

LEGENDRE, P. \& L. LEGENDRE. 1998. Numerical Ecology, $2^{\text {nd }}$ English edition. Elsevier, Amsterdam.

LIUKKONEN, M., T. KAIRESALO \& E. Y. HAWORTH. 1997. Changes in the diatom community, including the appearance of Actinocyclus normanii f. subsalsa, during the biomanipulation of Lake Vesijarvi, Finland. European Journal of Phycology, 32: 353-361.

MEERHOFF, M., N. MAZZEO, B. MOSS \& L. RODRÍGUEZ-GALLEGO. 2003. The structuring 
role of free-floating versus submerged plants in a subtropical shallow lake. Aquatic Ecology, 37: 377-391.

METZELTIN, D., H. LANGE-BERTALOT \& F. GARCÍA RODRIGUEZ. 2005. Diatoms of Uruguay: taxonomy, diversity, biogeography. Iconographia Diatomologica, 15: 1-736.

MOURA, A. N., E. C. DO NASCIMIENTO \& E. W. DANTAS. 2012. Temporal and spatial dynamics of phytoplankton near farm fish in eutrophic reservoir in Pernambuco, Brazil. Revista de Biología Tropical, 60: 581-597.

NRC. 2011. Natural Resources Canada-Canadian Diatom Database: www.nrcan.gc.ca

PARRA, O., C. VALDOVINOS, R. URRUTIA, M. CISTERNAS, E. HABIT \& M. MARDONES. 2003. Caracterización y tendencias tróficas de cinco lagos costeros de Chile Central. Limnetica, 22: 51-83.

PETERSON, C. G. \& R. J. STEVENSON. 1992. Resistance and resilience of lotic algal communities: Importance of disturbance timing and current. Ecology, 73: 1445-1461.

PIENITZ, R., K. ROBERGE \& W. F. VINCENT. 2006. Three hundred years of human-induced change in an urban lake: Paleolimnological analysis of Lac Saint-Augustin, Québec City, Canada. Canadian Journal of Botany, 84: 303-320.

RÄSÄNEN, J., T. KAUPPILA \& V-P. SALONEN. 2006. Sediment-based investigation of naturally or historically eutrophic lakes-implications for lake management. Journal of Environmental Management, 79: 253-265.

REAVIE, E. D., J. P. SMOL, I. D. SHARPE, L. A. WESTENHOFER. \& A-M. ROBERTS. 2000. Paleolimnological analyses of cultural eutrophication patterns in British Columbia lakes. Canadian Journal of Botany, 78: 873-888.

REYNOLDS, C. 2006. Ecology of phytoplankton. Cambridge University Press. Cambridge, England.

RIEDINGER-WHITMORE, M., T. WHITMORE, J. SMOAK, M. BRENNER, A. MOORE, J. CURTIS \& C. SCHELSKE. 2005. Cyanobacterial proliferation is a recent response to eutrophication in many Florida lakes: A paleolimnological assessment. Lake and Reservoir Management, 21: 423435.

RODRÍGUEZ-GALLEGO, L. 2003. Estrategias para el control de la carga de nutrientes del Lago Rodó. Master's Thesis, Facultad de Ciencias, Universidad de la República. Montevideo.
RODRÍGUEZ-GALLEGO, L., N. MAZZEO, J. GORGA, M. MEERHOFF, J. CLEMENTE, C. KRUK, F. SCASSO, G. LACEROT, J. GARCÍA \& F. QUINTANS. 2004. The effects of an artificial wetland dominated by free-floating plants on the restoration of a subtropical, hypertrophic lake. Lakes \& Reservoirs: Research and Management, 9: 203-215.

SAROS, J., D. CLOW, T. BLETT \& A. WOLFE. 2011. Critical nitrogen deposition loads in highelevation Lakes of the Western US inferred from paleolimnological records. Water, Air, \& Soil Pollution, 216: 193-202.

SCASSO, F., N. MAZZEO, J. GORGA, C. KRUK, G. LACEROT, J. CLEMENTE, D. FABIÁN \& S. BONILLA. 2001. Limnological changes in a sub-tropical shallow hypertrophic lake during its restoration: two years of a whole-lake experiment. Aquatic Conservation: Marine and Freshwater Ecosystems, 11: 31-44.

SCHELSKE, C. \& W. KENNEY. 2001. Model erroneously predicts failure for restoration of Lake Apopka, a hypereutrophic, subtropical lake. $\mathrm{Hy}$ drobiologia, 448: 1-5.

SCHIEMER, F. \& K. T. BOLAND. 1996. Perspectives in tropical limnology. SPB Academic Publishing.

SMOL, J. P. 2002. Pollution of lakes and rivers a paleoenvironmental perspective. Blackwell Publishers. London, England.

SOMMARUGA, R. 1995. Microbial and classical food webs: a visit to a hypertrophic lake. Microbiology Ecology, 17: 257-270.

STOERMER, E. \& J. P. SMOL. 1999. The Diatoms: applications for the Environmental and Earth Sciences. Cambridge University Press. Cambridge, England.

TALLING, J. F. 1957. Photosynthetic characteristics of some freshwater plankton diatoms in relation to underwater radiation. New Phytologist, 56: 38-50.

VALERO-GARCÉS, B., P. GONZÁLEZ-SAMPÉRIZ, A. NAVAS, J. MACHÍN, P. MATA, A. DELGADO-HUERTAS, R. BAO, A. MORENO, J. CARRION, A. SCHWALB \& A. GONZÁLEZBARRIOS. 2006. Human impact since medieval times and recent ecological restoration in a Mediterranean lake: Laguna Zoñar, southern Spain. Journal of Paleolimnology, 35: 441-465.

VAN DONK, E. \& S. KILHAM. 1990. Temperature effects on silicon- and phosphorus-limited growth 
and competitive interactions among three diatom. Journal of Phycology. 26: 40-45.

WANG, L., P. RIOUAL,V. PANIZZO, H. LU, Z. GU, G. CHU, D. YANG, J. JINGTAI, J. LIU \& A. MACKAY. 2012. A 1000-yr record of environmental change in NE China indicated by diatom assemblages from maar Lake Erlongwan. Quaternary Research, 78: 24-34.

WESSELS, M., K. MOHAUPT, R. KÜMMERLIN
\& A. LENHARD. 1999. Reconstructing past eutrophication trends from diatoms and biogenic silica in the sediment and the pelagic zone of Lake Constance, Germany. Journal of Paleolimnology, 21: 171-192.

YAO, M., Y-L. LI, X-D. YANGA \& Q. LIU. 2011. Three-year changes in planktonic diatom communities in a eutrophic lake in Nanjing, Jiangsu Province, China. Journal of Freshwater Ecology, 26: 133-14. 